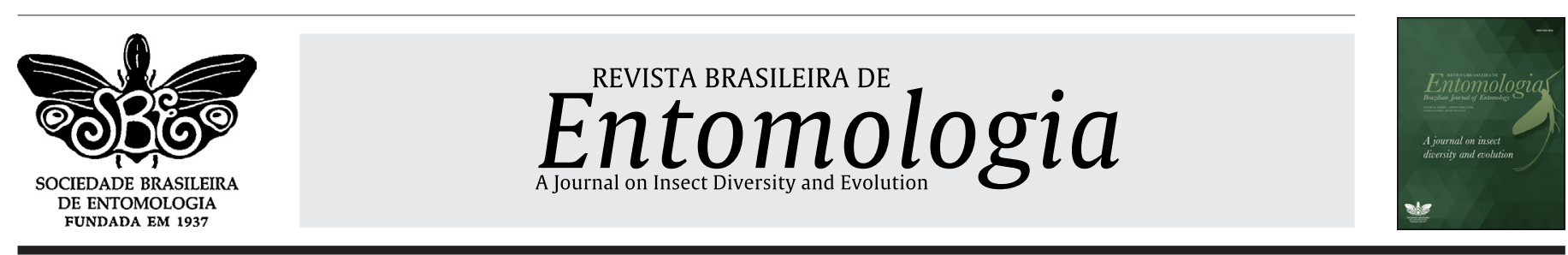

\title{
Selection and molecular characterization of Bacillus thuringiensis strains efficient against soybean looper (Chrysodeixis includens) and Spodoptera species
}

\author{
Karine Silva de Carvalho ${ }^{*}$ (D), Tatiane Aparecida Nascimento Barbosa ${ }^{1}$ (D), \\ Ubiraci Gomes de Paula Lana ${ }^{2}$, Fernando Hercos Valicente ${ }^{2}$ \\ ${ }^{1}$ Universidade Federal de Lavras (UFLA), Lavras, MG, Brasil \\ ${ }^{2}$ Embrapa Milho e Sorgo, Núcleo de Biologia Aplicada (NBA), Sete Lagoas, MG, Brasil
}

\section{A R T I C L E I N F O}

\section{Article history:}

Received 11 August 2020

Accepted 23 November 2020

Available online 16 December 2020

Associate Editor: Regiane Cristina Bueno

\section{Keywords:}

Multiple pest control

Lepidoptera

B. thuringiensis

Molecular approach

\begin{abstract}
A B S T R A C T
Soybean looper (Chrysodeixis includens) and Spodoptera group are important defoliators insects responsible for significant yield losses in soybean, cotton and maize in Brazil. Bioinsecticides and transgenic plants expressing insecticidal proteins from Bacillus thuringiensis are among the most used sustainable control methods for pest control in agriculture, especially for several lepidopteran species. To provide new components for insect control, this study aimed to select and characterize $B$. thuringiensis strains toxic to $C$. includens, $S$. cosmioides, $S$. eridania, and $S$. frugiperda. We performed initial bioassays with fifty $B$. thuringiensis strains for $C$. includens and selected four strains - 1608A, 726, 773, and 775E - that caused high larval mortality (100\%) to be tested against Spodoptera species. These strains harbored cry insecticidal genes, megaplasmids, absence of $\beta$-exotoxin and showed two major proteins about 65 and $130 \mathrm{kDa}$ in SDS-page attributed to Cry protein classes toxic to lepidopteran species. The 1608A and 775E strains also showed high toxicity to Spodoptera species that demonstrate great potential for $B$. thuringiensis-based bioproduct development and as sources of new insecticidal genes for transgenic crops for multiple pest control relevant in the Brazilian agricultural system.
\end{abstract}

\section{Introduction}

The soybean looper, Chrysodeixis includens [Walker, 1858] (Lepidoptera: Noctuidae), is a polyphagous pest present in several countries of the American continent, with occurrence from the north of the USA to the south of South America. C. includens causes economic losses in diverse crops (Moscardi et al., 2012; Souza et al., 2019) and, it is considered one of the most important pests in soybean crop in Brazil. The Spodoptera genus are composed of important species of defoliator caterpillars, such as $S$. cosmioides, $S$. eridania and the fall armyworm, S. frugiperda (JE Smith), responsible for significant losses in maize production in Brazil, African continent, India, and China (Goergen et al., 2016; Guo et al., 2018; Sharanabasappa et al., 2018). Control of these insects is mainly achieved using chemical insecticides, and it requires control actions throughout most of the growing crop seasons. Biological control using Bacillus thuringiensis(Berliner) is promising alternative to control these insects.

B. thuringiensis is an aerobic Gram-positive bacterium that produces protein crystalline inclusions named Cry proteins during the stationary phase and encoded by different cry genes (Angus, 1954; Bechtel and

\footnotetext{
* Corresponding author:

E-mail: karinescarvalho00@gmail.com (K.S. Carvalho)
}

Bulla, 1976). These genes are mainly present in the plasmids that are considered important elements of genetics bacterial, although some these genes may also be present on chromosome (Liu et al., 2010). Crystal proteins are composed of one or more Cry and/or Cyt proteins, cytolytic proteins named delta $(\delta)$ endotoxins. These components determine $B$. thuringiensis pathogenicity (Schnepf et al., 1998). B. thuringiensis strains also produce other types of insecticidal proteins, such as the vegetative insecticidal proteins (Vip) and secreted insecticidal proteins (Sip), synthesized during the vegetative phase growth not forming any crystals. In addition, are capable of producing non-proteinaceous, thermostable and secretable secondary metabolites exhibiting non-specific toxic activity not only against a wide range of insects but also against mammals (Levinson et al., 1990). Due to these dangerous characteristics, it is important to detect isolates that produce $\beta$-exotoxins to no use them in biopesticide formulation (WHO, 1999).

The insecticide activities of entomopathogenic microorganisms such as B. thuringiensis have succeeded in promoting the pest control. The damage caused by the high incidence of defoliating caterpillars is constant in each crop. Therefore, is important the search for new isolates with toxic activities for different pest species for production of new agricultural products such as biopesticides, and the development 
of transgenic plants (Lee et al., 2015; Mukhija and Khanna, 2018). The use of molecular strategies for the characterization of efficient B. thuringiensis isolates is widely applied and efficient to distinguish their properties mainly in relation to the gene content (Carozzi et al., 1991; Valicente et al., 2010, Chandrasekaran et al., 2018).

In order to provide new components for insect control, this study aimed to select and characterize $B$. thuringiensis strains toxic to C. includens and three Spodoptera species (S. cosmioides, S. eridania and $S$. frugiperda).

\section{Materials and methods}

\section{B. thuringiensis strains}

Fifty strains of $B$. thuringiensis from Multifunction Microorganisms Collection of Embrapa Milho e Sorgo (Sete Lagoas, MG, Brazil) were used for bioassays against $C$. includens. These isolates were previously collected from soil samples and grain dust from different locations in Brazil (Valicente and Barreto, 2003). Each B. thuringiensis strain was inoculated into Petri dishes with Luria Bertani (LB) agar medium enriched with mineral salts $\left(\mathrm{FeSO}_{4}, \mathrm{ZnSO}_{4}, \mathrm{MnSO}_{4}\right.$ and $\mathrm{MgSO}_{4}$ ) and incubated at $29^{\circ} \mathrm{C}$ for $72 \mathrm{~h}$ for complete sporulation (Valicente and Mourão, 2008). Bacterial content was collected, diluted in $0.05 \%(\mathrm{v} / \mathrm{v})$ Tween-20 and the spores counted with a Neubauer chamber.

\section{Bioassays against $C$. includens}

Artificial diet was poured on 128-well bioassay trays ( $B I O-B A-128$, CD International Inc., USA) at a volume of $1 \mathrm{~mL}$ per well (Greene et al., 1976; Valicente and Barreto, 2003). After solidification, $50 \mu \mathrm{L}$ of the mixture of spores and crystals in a concentration of $10^{9}$ spores $/ \mathrm{mL}$ was applied on the diet surface. Neonate larvae were placed individually in each cell and sealed with a plastic lid. The bioassay consisted of three replicates with 32 larvae of $C$. includens for each $B$. thuringiensis strain, and water was used as negative control. The experimental design was completely randomize. Larvae were maintained at $26 \pm 2^{\circ} \mathrm{C}$ and mortality assessed after three days. Mortality rate was calculated using the number of dead caterpillars / number of surviving caterpillar x 100. Percentage mortality data were transformed before analysis using the Box-Cox transformation (Box and Cox, 1964). The mortality was submitted to analysis of variance (ANOVA) and the means compared using Scott-Knott test with $5 \%$ of significance using Assistat 7.7 program (Silva and Azevedo, 2016). B. thuringienis strains that caused mortality above $70 \%$ were evaluated for the production of $\beta$-exotoxins, presence of crygenes, plasmid patterns, protein profiles, and used in bioassays against Spodoptera species.

\section{Detection of cry insecticidal genes}

DNA extraction was performed according Shuhaimi et al. (2001) and used as template for PCR with 18 primers designed to amplify the cry1, cry2, and cry9 insecticidal genes (Ceron et al., 1994; Ceron et al., 1995; Valicente et al., 2010) (Table 1). The amplification reactions were carried out in a $25 \mu \mathrm{L}$ reaction volume using $10 \mathrm{ng}$ of genomic DNA, $2 \mathrm{mM} \mathrm{MgCl}_{2}, 0,125 \mathrm{mM}$ of dNTP, $0.5 \mu \mathrm{M}$ of each primer and $2 \mathrm{U}$ of Taq DNA polymerase (KAPA Biosystems, USA). The amplified fragments were electrophoresed on a $1.5 \%(\mathrm{w} / \mathrm{v})$ agarose gel, stained with GelRed ${ }^{\mathrm{TM}}$ (Biotium, USA) and photographed using L-PIX Image transilluminator (Loccus Biotechnology, USA).

\section{Detection of $\beta$-exotoxin}

The production of thermostable $\beta$-exotoxins by $B$. thurigiensis strains was performed using neonate larvae of $S$. frugiperda (Hornby and Gardner, 1987). Each strain was grown in LB medium enriched with mineral salts (Valicente and Mourão, 2008) and incubated at $28^{\circ} \mathrm{C}$ for $144 \mathrm{~h}$ at $200 \mathrm{rpm}$. B. thuringiensis cultures were centrifuged at $10,000 \mathrm{x}$ g for $10 \mathrm{~min}$, and the supernatant autoclaved at $121^{\circ} \mathrm{C}$ for $20 \mathrm{~min}$. Filtration of the supernatant was performed using TTP brand paper filters with $0.22 \mu \mathrm{m}$. For the bioassays, $165 \mu \mathrm{L}$ of the filtered supernatants were superficially applied in approximately $1 \mathrm{~cm}^{3}$ of artificial diet (Valicente and Barreto, 2003), and placed in plastic recipients sealed with a plastic lid. Each treatment consisted of three replicates with 24 larvae. Water was used as negative control and HD125 strain as a positive control ( $\beta$-exotoxin producer). $\beta$-exotoxins production by $B$. thuringiensis strains were determined by larvae growth inhibition or high mortality of $S$. frugiperda after eight days of inoculation (Pinheiro, 2013). The treatment means were submitted to analysis of variance (ANOVA) and the means compared using Scott-Knott test with $5 \%$ of significance using Assistat 7.7 program (Silva and Azevedo, 2016). In addition, a PCR analysis performed to detect the presence of thuE gene in $B$. thuringiensis strains genome, that is strongly associated with the synthesis of type I of $\beta$-exotoxin (Sauka et al., 2014).

Plasmidial profile

The strains were submitted to two methods of plasmid extraction. The first extraction method was according to Fagundes et al. (2011) and the second using the commercial Maxi Plasmid Purification kit (Qiagen, USA) according to the manufacturer's recommendations. To analyze the integrity and plasmid profile, the samples were electrophoresed on a $0.5 \%(\mathrm{w} / \mathrm{v})$ agarose gel at $80 \mathrm{~V}$. The gel was stained with GelRed (Biotium, USA) and photographed using L-PIX Image transilluminator (Loccus Biotechnology, USA).

\section{Protein profile by SDS-PAGE}

B. thuringiensis strains were inoculated in LB medium enriched with mineral salts and incubated at $30^{\circ} \mathrm{C}$ for $96 \mathrm{~h}$ at $245 \mathrm{rpm}$, until complete sporulation. Total proteins were purified (Valicente and Lana, 2008) and quantified by the Bradford method (Bradford, 1976) in the UV-mini-1240 Spectrophotometer (Shimadzu, USA). Protein samples were treated with trypsin and incubated at $37^{\circ} \mathrm{C}$ for $2 \mathrm{~h}$ (Valicente and Lana, 2008). The reaction was inactivated with $1 \mathrm{mM}$ PMSF (phenylmethylsulfonyl fluoride), and protein profile of $B$. thuringiensis strains analyzed by electrophoresis on $12 \%(\mathrm{w} / \mathrm{v}$ ) polyacrylamide gel (SDS-PAGE). The gel was stained with coomassie brilliant blue R250 solution and molecular mass of the proteins was estimated by comparison to SeeBlue ${ }^{\circledast}$ Plus2 Pre-Stained Standard marker (Invitrogen, USA).

\section{Bioassays against Spodoptera spp.}

Mortality tests were performed with neonate larvae of $S$. eridania, $S$. cosmioides, and $S$. frugiperda with the $B$. thuringiensis strains that caused mortality above $70 \%$ in $C$. includens. The bioassays and statistical analysis were conducted following the same steps previously described for bioassays to $C$. includens. 
Table 1

Primers used for detection of cry insecticidal genes in Bacillus thuringiensis strains.

\begin{tabular}{|c|c|c|c|c|}
\hline Primer sequences (5'-3') & Target gene & $\operatorname{Tm}\left({ }^{\circ} \mathrm{C}\right)$ & Fragment size (bp) & Reference \\
\hline CGCCACAGGACCTCTTAT & \multirow{2}{*}{ cry $1 \mathrm{Ab}$} & \multirow{2}{*}{55} & \multirow{2}{*}{232} & \multirow{2}{*}{ Valicente et al. (2010) } \\
\hline TGCACAACCACCTGACCCA & & & & \\
\hline AATTTGCCATCCGTCGTA & \multirow[b]{2}{*}{ cry $1 \mathrm{Ab}$} & \multirow[b]{2}{*}{55} & \multirow[b]{2}{*}{418} & \multirow{2}{*}{ Valicente et al. (2010) } \\
\hline TTGTGGTAGAAGCGTAGCGA & & & & \\
\hline GTTAGATTAAATAGTAGTGG & \multirow{2}{*}{ cry 1 Ac } & \multirow{2}{*}{53} & \multirow{2}{*}{180} & \multirow{2}{*}{ Ceron et al. (1994) } \\
\hline TGTAGCTGGTACTGTATTG & & & & \\
\hline CTTCATCACGATTGGAGTAA & \multirow{2}{*}{ cry1B } & \multirow{2}{*}{55} & \multirow{2}{*}{367} & \multirow{2}{*}{ Ceron et al. (1994) } \\
\hline CATAATTTGGTCGTTCTGTT & & & & \\
\hline AAAGATCTGGAACACCTTT & \multirow{2}{*}{ сry1C } & \multirow{2}{*}{58} & \multirow{2}{*}{130} & \multirow{2}{*}{ Ceron et al. (1994) } \\
\hline САААСТСТАААТССТТТСАС & & & & \\
\hline CTGCAGCAAGCTATCCAA & \multirow{2}{*}{ cry1D } & \multirow[b]{2}{*}{55} & \multirow[b]{2}{*}{290} & \multirow{2}{*}{ Ceron et al. (1994) } \\
\hline ATTTGAATTGTCAAGGCCTG & & & & \\
\hline GGAACCAAGACGAACTATTGC & \multirow{2}{*}{ cry1Ea/cry1Eb } & \multirow{2}{*}{56} & \multirow{2}{*}{147} & \\
\hline 5 GGTTGAATGAACCCTACTCCC & & & & Ceron et al. (1995) \\
\hline TAATAGGGCGGAATTTGGAG & & & & \\
\hline AAGCCCCAGTACATAATGAG & сгу1Fa1/сrу1 Fb & 55 & 283 & Valicente et al. (2010) \\
\hline TGCGAATGAATTATGGGTC & & & & \\
\hline CACAAAGTGTAACCAATTTTAC & сry1Fb1 & 55 & 377 & Valicente et al. (2010) \\
\hline ATATGGAGTGAATAGGGCG & & & & \\
\hline TGAACGGCGATTACATGC & cry1G & 55 & 235 & Ceron et al. (1995) \\
\hline GGGGCGACTAATCTCAATCA & & & & \\
\hline AGGTGTTCCCGAAGGACTTT & сгу2Аа & 53 & 318 & Fagundes et al. (2019)* \\
\hline TGTTAAATGGATTTAGTGGTGCT & CrOPAh & & & \\
\hline CAAATGGCGTTAACAATGG & сгу $2 \mathrm{Ab}$ & 53 & 201 & Fagundes et al. (2019) \\
\hline ACAGCAGTCGCTAGCCTTGT & GripAr & & & \\
\hline CAAATTGTGGATTGCCGTTA & сгу 2 Ас & 55 & 475 & Fagundes et al. (2019) \\
\hline ACGATATCGCCACCTTTGTC & CIVDAd & 53 & 282 & \\
\hline AGGTGTTCCTGAAGGGCTTT & сту $2 \mathrm{Ad}$ & 53 & 282 & Fagundes et al. (2019) \\
\hline TTATCGGGTGAATCTCTAGAACG & Cro & 52 & 212 & Гาondos \\
\hline TGTTAAAGTCCCCGTTTTGC & стуу & 53 & 343 & ragundes et al. (2019)" \\
\hline CATAATAGGCGATGCAGCAA & crvaA & 53 & 395 & Farundes et al (2019)* \\
\hline CTAACGAGCCACCATTCGTT & Гулй & כل & נכנכ & 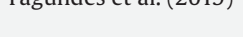 \\
\hline GTTGATACCCGAGGCACA & CrVA & 60 & 571 & Farundes et al (2019)* \\
\hline CCGCTTCCAATAACATCTTTT & & 00 & $5 / 1$ & ragundes et al. (2019) \\
\hline TCATTGGTATAAGAGTTGGTGATAGAC & crvaB & 60 & 407 & Farundec et al (2019)* \\
\hline CCGCTTCCAATAACATCTTTT & (1УכD & 00 & 702 & 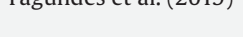 \\
\hline AATAGACCAAATGGCGCAAG & CroD & 60 & 382 & Farundes et al (2019)* \\
\hline AATCCATTGCCGTCAAAGTC & Сту9D & 00 & 382 & ragundes et al. (2019) \\
\hline
\end{tabular}

*Unpublished data

\section{Results and discussion}

Although $C$. includens it is an important pest of many crops as soybean, maize, cotton, wheat and bean, studies about its control with $B$. thuringiensis are scarce (Isakova et al., 2007; Barreto, 2012; Specht et al., 2015). To give some insights to these questions, we tested the efficiency of $B$. thuringiensis strains for $C$. includens larvae control and the mortality ranged from 4 to $100 \%$, of which $92 \%$ of strains caused low mortality, less than 33\%. Strains 1608A, 726, 773 and 775E caused high mortality of $C$. includens (100\%) and therefore, were selected for molecular characterization and bioassays against Spodoptera species.

Some $B$. thuringiensis strains are capable of producing thermostable and secretable secondary metabolites exhibiting non-specific toxic activity, commonly known as $\beta$-exotoxins (Liu et al., 2014). No $\beta$-exotoxins activity was detected in the supernatants of 1608A, 726, 773 and $775 \mathrm{E}$ strains, demonstrated by low mortality against $S$. frugiperda that ranged from 8.3 to $13.0 \%$ without significant difference when compared to the negative control that caused low mortality of $8.3 \%$. The positive control (HD-125 strain) caused $29.2 \%$ mortality against $S$. frugiperda differing significantly from the other treatments. We observed differences in larval weight, growth and development of $S$. frugiperda after eight days of exposure (Fig. 1). Average weight of larvae fed with supernatants of B. thuringiensis ranged from 26.4 to $32.1 \mathrm{mg}$ differing from the positive control that showed an average weight of $0.55 \mathrm{mg}$, indicating that these strains did not produce $\beta$-exotoxins.

To confirm these results, a PCR analysis was performed to detect the presence of $t h u E$ gene. No amplification product was observed among select strains (Fig. 2). Therefore, the B. thuringiensis strains $1608 \mathrm{~A}, 726,773$ and $775 \mathrm{E}$ are safe to be used in large scale fermentation systems and formulations of biopesticides. Absence of $\beta$-exotoxins is a requirement for $B$. thuringiensis formulations used in Europe, the US, Canada, and Brazil since the exposure to these toxins pose a health risk (Glare and O'Callaghan, 2000).

The presence of insecticidal genes detected with specific primers for cry genes is widely used for characterization of $B$. thuringiensis strains, allowing the screening, classification, and prediction to their insecticidal activities (Jain et al., 2017). Amplification products with the expected size were observed for target genes, except for $c r y 1 \mathrm{Ea} /$ cry $1 \mathrm{~Eb}$ genes. The genes cry $1 \mathrm{Ab}$, cry $1 \mathrm{G}$, cry2 $\mathrm{Ab}$, cry $2 \mathrm{Ac}$ and cry2 Ad were found 


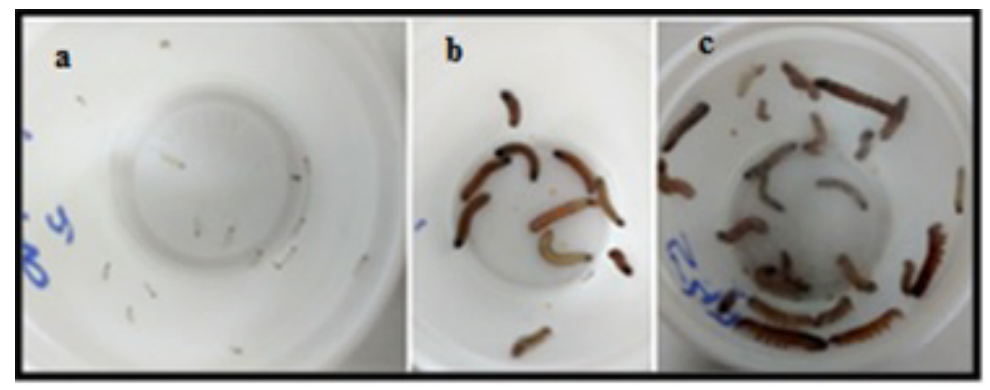

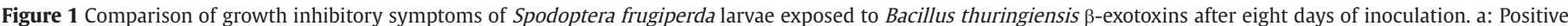
control (strain HD-125); b: Negative control (water); c: Strain 773.

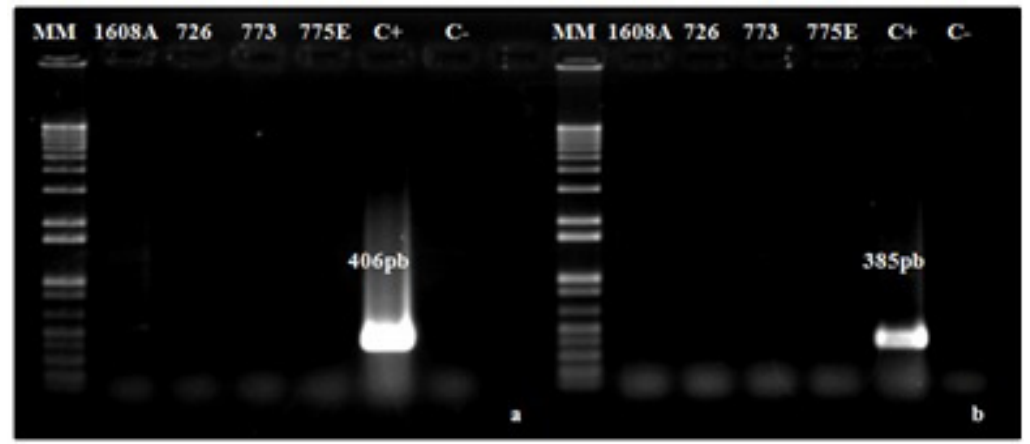

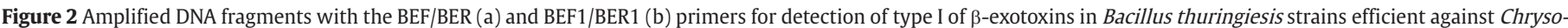
deixis includens. C+: Positive control (HD-125 strain); C-: Negative controle (water); MM: 1 Kb DNA ladder plus (Invitrogen, USA.

Table 2

Characterization of genes in B. thuringiensis strains toxic to Chrysodeixis includens.

\begin{tabular}{|c|c|c|c|c|}
\hline \multirow[t]{2}{*}{ Target genes } & \multicolumn{4}{|c|}{ B. thuringiensis strains ${ }^{\mathrm{a}}$} \\
\hline & $1608 \mathrm{~A}$ & 726 & 773 & $775 \mathrm{E}$ \\
\hline сгу $1 \mathrm{Ab}(1)$ & $\mathrm{x}$ & $\mathrm{x}$ & $\mathrm{x}$ & $\mathrm{x}$ \\
\hline сry $1 \mathrm{Ab}$ & $\mathrm{x}$ & & & \\
\hline сry1Ac & & & & $\mathrm{x}$ \\
\hline сry $1 \mathrm{~B}$ & & & & $\mathrm{x}$ \\
\hline сry $1 \mathrm{C}$ & & $\mathrm{x}$ & $\mathrm{x}$ & \\
\hline cry $1 \mathrm{D}$ & & & & $\mathrm{x}$ \\
\hline сrу1Ea/cry $1 \mathrm{~Eb}$ & & & & \\
\hline сгу $1 \mathrm{Fa} 1 /$ сту $1 \mathrm{Fb}$ & $\mathrm{x}$ & & & \\
\hline сrу1 $1 \mathrm{Fb}$ & $\mathrm{x}$ & & & \\
\hline сту $1 \mathrm{G}$ & $\mathrm{x}$ & $\mathrm{x}$ & $\mathrm{x}$ & $\mathrm{x}$ \\
\hline сту2Аа & $\mathrm{x}$ & $\mathrm{x}$ & & \\
\hline cry $2 \mathrm{Ab}$ & $\mathrm{x}$ & $\mathrm{x}$ & $\mathrm{x}$ & $\mathrm{x}$ \\
\hline сrу2Ac & $\mathrm{x}$ & $\mathrm{x}$ & $\mathrm{x}$ & $\mathrm{x}$ \\
\hline cry2Ad & $\mathrm{x}$ & $\mathrm{x}$ & $\mathrm{x}$ & $\mathrm{x}$ \\
\hline сry9 & $\mathrm{x}$ & & & $\mathrm{x}$ \\
\hline сгу9Aа & $\mathrm{x}$ & & & \\
\hline $\operatorname{cry} 9 \mathrm{~A}$ & $\mathrm{x}$ & & & \\
\hline сrу9в & $x$ & & & \\
\hline
\end{tabular}

${ }^{a}(x)$ Determines the presence of genes.

in all strains tested (Table 2). Cry1 and Cry2 class of proteins are related to toxicity against $C$. includens (Van Frankenhuyzen, 2009; Bel et al., 2017, 2019), and for other lepidopteran species, including S. frugiperda (Knaak et al., 2010). Strain 1608A harbored several insecticidal genes, including cry9 class genes that are promising tools for pest control (Jansens et al., 1997) with toxic activity to several important insects, and a good strategy for delaying development of insect resistance in the field (Kuvshinov et al., 2001; Wang et al., 2018).

The diversity of cry genes in B. thuringiensis genome may occur due to environmental factors of the places and substrates that strains were collected. The investigation of isolates collected from different ecological and geographical sources enables relating gene content results to potential target insects and may be a good strategy for selecting new isolates with broad toxic activity (Djenane et al., 2017).

We used two methods of DNA extraction and both allowed to detect extrachromosomal DNA on agarose gel (Fig. 3). A single megaplasmid was observed in three out of four samples analyzed, with differences in their sizes, except for the strain 726, which did not show any megaplasmid when extracted with the method proposed by Fagundes et al. (2011). In contrast, the use of commercial kit allowed the detection of megaplasmids in all studied B. thuringiensis strains, specially in the strain 773 that showed two megaplasmids with different sizes. Only method reported by Fagundes et al. (2011) was efficient to detect a large number of small plasmids in all strains. Thus, this strategy showed to be better for analysis mainly of the small plasmids, while the use of commercial kit showed better for megaplasmids extraction.

The $B$. thuringiensis showed from 1 to 6 plasmids. Strains 726 and 773 showed similar patterns of small plasmids, both presenting only one small plasmid with sizes of approximately 10,000 bp. Although these strains showed similar plasmid profiles, the DNA sequences of these plasmids may be different, which should be considered in future work (Fagundes et al., 2011). Although some studies have focused on the importance of megaplasmids as host sites for cry genes that encode bioinseticidal delta-endotoxins, small plasmids are also found in B. thuringiensis that contribute to the biology of their host ( $\mathrm{Li}$ et al., 2014). Thus, both molecules are important to be sequenced to detect presence of new insecticidal proteins.

The protein profile of all strains evaluated presented two main bands of pro-toxin of $\sim 130$ and $\sim 65 \mathrm{kDa}$ (Fig. 4). The protein patterns presented by the $B$. thuringiensis strains are related with the proteins of classes Cry1, Cry2, and Cry9 that are toxic to species of Lepidoptera order, and considered as a good alternative for the management for insect control (Crickmore et al., 2016). In this study the pro-toxins produced by strains were digested using the trypsin protease to simulate in vivo activity. After digestion, all strains showed toxins with 

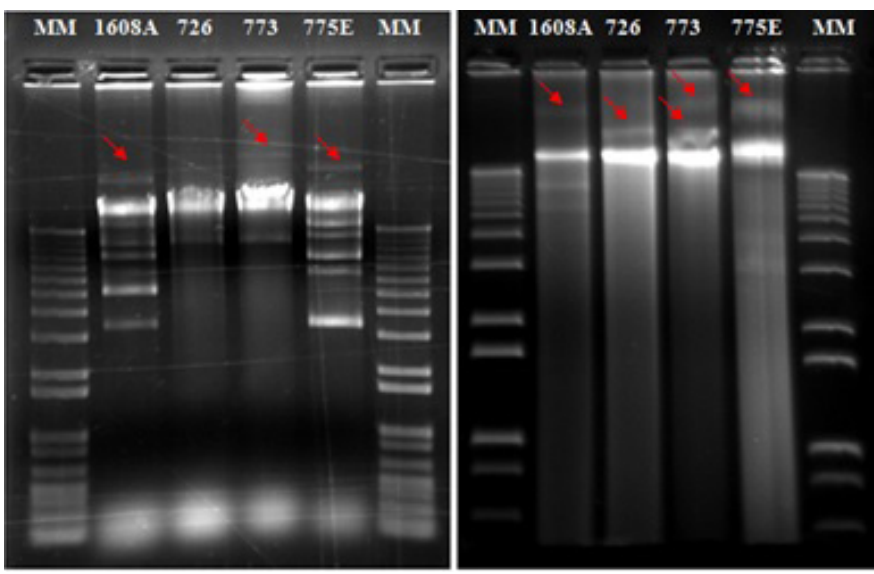

Figure 3 Plasmid profiles of Bacillus thuringiensis efficient strains against Chrysodeixis includens. a: DNA extraction according to Fagundes et al. (2011); b: DNA extraction using QIAGEN kit (Invitrogen, USA). MM: $1 \mathrm{~Kb}$ DNA ladder plus (Invitrogen, USA. The red rows indicate megaplasmids.

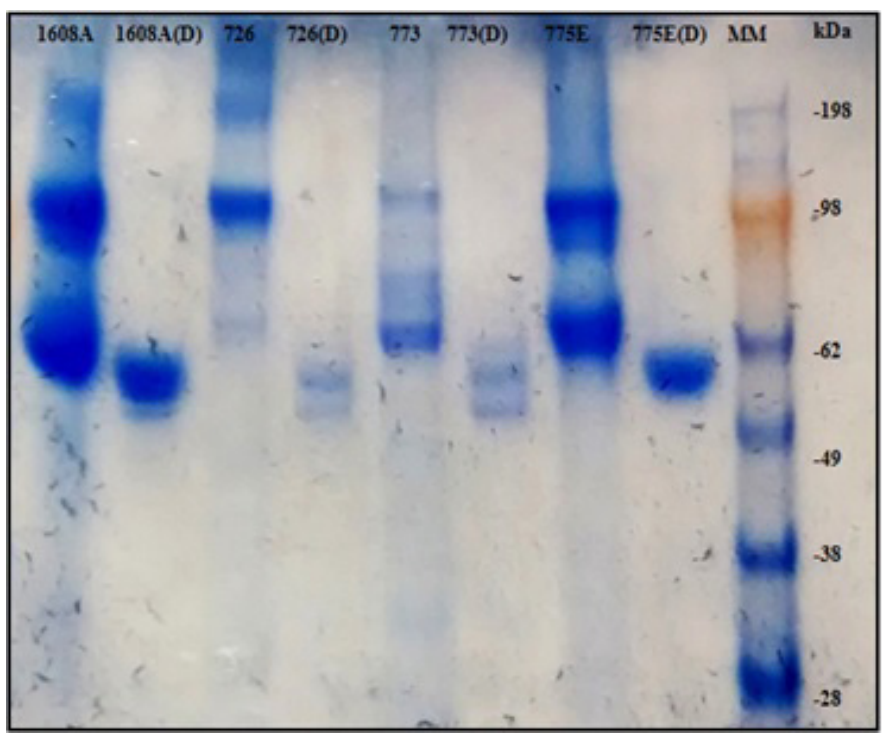

Figure 4 Profile of total and digested trypsin proteins produced by Bacillus thuringiensis strains eficiente against Chrysodeixis includens. (D) Proteins digested with trypsin; MM: SeeBlue ${ }^{\circledR}$ Plus2 Pre-Stained Standard Marker (Invitrogen, USA).

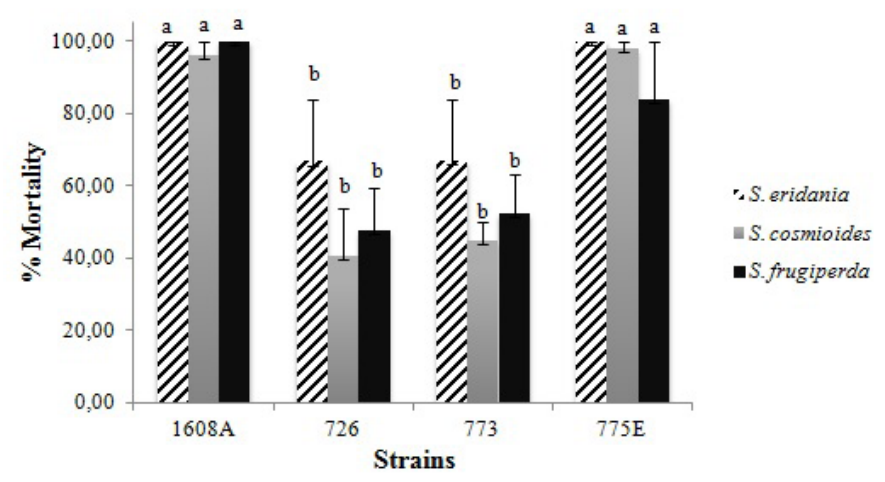

Figure 5 Toxicity of Bacillus thuringiensis strains against three Spodoptera species. Means followed by the same letter do not differ statistically from one another by the Scott-Knott test at the 5\% probability level.

$60 \mathrm{kDa}$ size (Fig. 4), frequently associated with activated Cry proteins (Maagd et al., 2003). This step of protein activation is important and crucial in understanding the mechanism of action of these proteins in target insects.
To select $B$. thuringiensis strains with high activity against multiple insects, we tested the four strains efficient against $C$. includens in S. eridania, S. cosmioides and S. frugiperda. Strains $1608 \mathrm{~A}$ and $775 \mathrm{E}$ showed mortality rates between $80-100 \%$ for the three species $(F=5.724$; $\mathrm{p}<0.0001$; Fig. 5). The highest mortality was caused by 1608 A strain, that caused $100 \%$ mortality against S. eridania and S. frugiperda, and $775 \mathrm{E}$ strain caused $100 \%$ mortality against S. eridania. Several lepidopterans species respond differently to the proteins tested, allowing to divide into groups of more permissive or less permissive to the activation of $B$. thuringiensis toxins (Van Frankenhuyzen, 2009). An important aspect is the selection $B$. thuringiensis strains with high toxic activity for more than one pest and that produce proteins with different modes of action for obtaining new formulations to be used in agriculture (Bobrowski et al., 2001; Bobrowski et al., 2003).

Some insects of genus Spodoptera and C. includens are commonly found in soybean fields, making it a concern in the management of these species if infestation occurs in the same period (Marques et al., 2016; Silva et al., 2017; Sousa et al., 2019). The high insecticidal activity of $B$. thuringiensis strains described in this work makes them excellent candidates to $C$. includens, S. eridania, S. cosmioides and S. frugiperda control, a valuable tool in the Integrated Pest Management (IPM). Furthermore, their genome sequencing will contribute to deeper understanding of entomopathogenicity of these $B$. thuringiensis strains and as sources of new insecticidal genes for transgenic crops development.

\section{Acknowledgments}

We are grateful to Embrapa Milho e Sorgo and Coordenação de Aperfeiçoamento de Pessoal de Nível Superior (CAPES).

\section{Conflicts of interest}

The authors declare no conflict of interest. This research did not receive any specific grant from funding agencies in the public, commercial, or not-for-profit sectors.

\section{Author contribution statement}

This work was carried out in collaboration between all authors. All authors read and approved the final version of the manuscript.

\section{References}

Angus, T. A., 1954. A bacterial toxin paralysing silkworm larvae. Nature 173 (4403), 545-546. https://doi.org/10.1038/173545a0.

Barreto, M. R., 2012. Prospecção e Caracterização de Genes de Bacillus thuringiensis com Potencial Para o Controle de Insetos-praga da Cultura da Soja. Thesis, Federal University of Paraná.

Bechtel, D. B., Bulla, L. A., 1976. Electron microscope study of sporulation and parasporal crystal formation in Bacillus thuringiensis. J. Bacteriol. 127 (3), 1472-1481. https://doi.org/10.1128/JB.127.3.1472-1481.1976.

Bel, Y., Sheets, J. J., Tan, S. Y., Narva, K. E., Escriche, B., 2017. Toxicity and binding studies of Bacillus thuringiensis Cry1Ac, Cry1F, Cry1C, and Cry2A proteins in the soybean pests Anticarsia gemmatalis and Chrysodeixis (Pseudoplusia) includens. Appl. Environ. Microbiol. 83 (11), https://doi.org/10.1128/AEM.00326-17.

Bel, Y., Zack, M., Narva, K., Escriche, B., 2019. Specific binding of Bacillus thuringiensis Cry1Ea toxin, and Cry1Ac and Cry1Fa competition 
analyses in Anticarsia gemmatalis and Chrysodeixis includens. Sci. Rep. 9 (1), 1-7. https://doi.org/10.1038/s41598-019- 54850-3.

Bobrowski, V. L., Fiuza, L. M., Pasquali, G., Bodanese-Zanettini, M. H., 2003. Genes de Bacillus thuringiensis: uma estratégia para conferir resistência a insetos em plantas. Cienc. Rural 33 (5), 843-850. https:// doi.org/10.1590/S0103-84782003000500008.

Bobrowski, V. L., Pasquali, G., Bodanese-Zanettini, M. H., Fiuza, L. M., 2001. Detection of cry1 genes in Bacillus thuringiensis isolates from South of Brazil and activity against Anticarsia gemmatalis (Lepidoptera: noctuidae). Braz.J. Microbiol. 32 (2), 105-109. https:// doi.org/10.1590/S1517-83822001000200006.

Box, G. E., Cox, D. R, 1964. An analysis of transformations. J. R. Stat. Soc. 26(2), 211-252.

Bradford, M. M., 1976. A rapid and sensitive method for the quantitation of microgram quantities of protein utilizing the principle of protein-dye binding. Anal. Biochem. 72 (1-2), 248-254. https:// doi.org/10.1016/0003-2697(76)90527-3.

Carozzi, N. B., Kramer, V. C., Warren, G. W., Evola, S., Koziel, M. G., 1991. Prediction of insecticidal activity of Bacillus thuringiensis strains by polymerase chain reaction product profiles. Appl. Environ. Microbiol. 57 (11), 3057-3061. https://doi.org/10.1128/AEM.57.11.3057-3061.1991.

Ceron, J., Covarrubias, L., Quintero, R., Ortiz, A., Ortiz, M., Aranda, E., Bravo, A., 1994. PCR analysis of the cryl insecticidal crystal family genes from Bacillus thuringiensis. Appl. Environ. Microbiol. 60 (1), 353-356. https://doi.org/10.1128/AEM.60.1.353-356.

Ceron, J., Ortíz, A., Quintero, R., Güereca, L., Bravo, A., 1995. Specific PCR primers directed to identify cryl and crylII genes within a Bacillus thuringiensis strain collection. Appl. Environ. Microbiol. 61 (11), 3826-3831.

Chandrasekaran, R., Revathi, K., Senthil-Nathan, S., Kalaivani, K., Hunter, W. B., Duraipandiyan, V., Esmail, G. A., 2018. Eco-friendly formulation of wild Bacillus thuringiensis secondary metabolites through molecular characterization against the lepidopteran pest. Physiol. Mol. Plant Pathol. 101, 93-104. https://doi.org/10.1016/j. pmpp.2017.09.002.

Crickmore, N., Baum, J., Bravo, A., Lereclus, D., Narva, K., Sampson, K., Schnepf, E., Sun, M., Zeigler, D. R., 2016. Bacillus thuringiensis Toxin Nomenclature. Available in: http://www.btnomenclature. info/ (acessed 10 April 2019).

Djenane, Z., Nateche, F., Amziane, M., Gomis-Cebolla, J., El-Aichar, F., Khorf, H., Ferré, J., 2017. Assessment of the Antimicrobial Activity and the Entomocidal Potential of Bacillus thuringiensis Isolates from Algeria. Toxins (Basel) 9 (4), 139. https://doi.org/10.3390/ toxins9040139.

Fagundes, R. B. S., Picoli, E. A. T., Lana, U. G. P., Valicente, F. H., 2011. Plasmid patterns of efficient and inefficient strains of Bacillus thuringiensis against Spodoptera frugiperda (JE Smith) (Lepidoptera: noctuidae). Neotrop. Entomol. 40 (5), 600-606. https://doi.org/10.1590/S1519$566 X 2011000500012$.

Glare, T. R., O'Callaghan, M., 2000. Bacillus thuringiensis: Biology, Ecology and Safety, Wiley, Chichester, UK.

Goergen, G., Kumar, P. L., Sankung, S. B., Togola, A., Tamò, M., 2016. First report of outbreaks of the fall armyworm Spodoptera frugiperda (JE Smith)(Lepidoptera, Noctuidae), a new alien invasive pest in West and Central Africa. PLoS One 11 (10), e0165632. https://doi. org/10.1371/journal.pone.0165632.

Greene, G. L., Leppla, N. C., Dickerson, W. A., 1976. Velvetbean caterpillar: a rearing procedure and artificial medium. J. Econ. Entomol. 69 (4), 487-488. https://doi.org/10.1093/jee/69.4.487.

Guo, J., Zhao, J., He, K., Zhang, F., Wang, Z., 2018. Potential invasion of the crop- devastating insect pest fall armyworm Spodoptera frugiperda to China. Plant Protection. 44(6), 1-10. https://doi. org/16688/j.zwbh.2018452.

Hornby, J. A., Gardner, W. A., 1987. Dosage/mortality response of Spodoptera frugiperda (Lepidoptera: Noctuidae) and other Noctuid larvae to beta-exotoxin of Bacillus thuringiensis. J. Econ. Entomol. 80 (4), 925-929. https://doi.org/10.1093/jee/80.4.925.

Isakova, I. A., Isakov, Y. B., Rymar, S. E., Kordium, V. A., Fuxa, J. R., 2007. Specificity of Ukrainian Bacillus thuringiensis Berliner strains for agricultural pests of the Southeastern United States. J. Entomol. Sci. 42 (2), 272-285. https://doi.org/10.18474/0749-8004-42.2.272.

Jain, D., Sunda, S. D., Sanadhya, S., Nath, D. J., Khandelwal, S. K., 2017. Molecular characterization and PCR-based screening of cry genes from Bacillus thuringiensis strains. 3 Biotech. 7(1), 4. https://doi. org/10.1007/s13205-016-0583-7.

Jansens, S., Van Vliet, A., Dickburt, C., Buysse, L., Piens, C., Saey, B., Peferoen, M., 1997. Transgenic corn expressing a Cry9C insecticidal protein from Bacillus thuringiensis protected from European corn borer damage. Crop Sci. 37 (5), 1616-1624. https://doi.org/10.2135/ cropsci1997.0011183X003700050035x.

Knaak, N., Franz, A. R., Santos, G. F., Fiuza, L. M., 2010. Histopathology and the lethal effect of Cry proteins and strains of Bacillus thuringiensis Berliner in Spodoptera frugiperda JE Smith Caterpillars (Lepidoptera, Noctuidae). Braz. J. Biol. 70 (3), 677-684. https://doi.org/10.1590/ S1519-69842010000300028.

Kuvshinov, V., Koivu, K., Kanerva, A., Pehu, E., 2001. Transgenic crop plants expressing synthetic cry9Aa gene are protected against insect damage. Plant Sci. An Int. J. Exp. Plant Biol. 160, 341-353.

Lee, Y. K., Jin, N. Y., Lee, B. R., Seo, M. J., Youn, Y. N., Gill, S. S., Yu, Y. M., 2015. Isolation and characterization of new Bacillus thuringiensis strains with insecticidal activity to difficult to control lepidopteran pests. J. Facul. Agricul. 60 (1), 103-112.

Levinson, B. L., Kasyan, K. J., Chiu, S. S., Currier, T. C., Gonzalez, J. M., 1990. Identification of beta-exotoxin production, plasmids encoding beta-exotoxin, and a new exotoxin in Bacillus thuringiensis by using high-performance liquid chromatography. J. Bacteriol. 172, 3172-3179.

Li, H., Liu, R., Shu, C., Zhang, Q., Zhao, S., Shao, G., Gao, J., 2014. Characterization of one novel cry8 gene from Bacillus thuringiensis strain Q52-7. World J. Microbiol. Biotechnol. 30 (12), 3075-3080. https://doi.org/10.1007/s11274-014-1734-9.

Liu, X. Y., Ruan, L. F., Hu, Z. F., Peng, D. H., Cao, S. Y., Yu, Z. N., Sun, M., 2010. Genome-wide screening reveals the genetic determinants of an antibiotic insecticide in Bacillus thuringiensis. J. Biol. Chem. 285 (50), 39191-39200. https://doi.org/10.1074/jbc.M110.148387.

Liu, X., Ruan, L., Peng, D., Li, L., Sun, M., Yu, Z., 2014. Thuringiensin: a thermostable secondary metabolite from Bacillus thuringiensis with insecticidal activity against a wide range of insects. Toxins (Basel) 6 (8), 2229-2238. https://doi.org/10.3390/toxins6082229.

Maagd, R. A., Bravo, A., Berry, C., Crickmore, N., Schnepf, H. E., 2003. Structure, diversity, and evolution of protein toxins from sporeforming entomopathogenic bacteria. Annu. Rev. Genet. 37 (1), 409-433. https://doi.org/10.1146/annurev.genet.37.110801.143042.

Marques, L. H., Castro, B. A., Rossetto, J., Silva, O. A. B. N., Moscardini, V. F., Zobiole, L. H. S., Fernandes, O. A., 2016. Efficacy of soybean's event DAS-81419-2 expressing Cry1F and Cry1Ac to manage key tropical lepidopteran pests under field conditions in Brazil. J. Econ. Entomol. 109 (4), 1922-1928. https://doi.org/10.1093/jee/tow153.

Moscardi, F., Bueno, A. D. F., Bueno, R. C. O. D. F., Garcia, A., 2012. Soybean response to different injury levels at early developmental stages. Cienc. Rural 42 (3), 389-394. https://doi.org/10.1590/S010384782012000300001.

Mukhija, B., Khanna, V., 2018. Cry Protein Profiling of Bacillus thuringiensis Isolated from Different Agro-Climate Soils of Punjab. Int. J. Curr. 
Microbiol. Appl. Sci. 7 (3), 2866-2870. https://doi.org/10.20546/ ijcmas.2018.703.330.

Pinheiro, H. D. 2013. Interação de proteínas Cry1A com as vesículas da borda escovada da membrana (BBMVs) do intestino médio de Spodoptera frugiperda e Diatraea saccharalis e avaliação do tempo de cultivo sobre a produção de $\beta$-exotoxina em isolados de Bacillus thuringiensis. Dissertation, Federal University of Lavras.

Sauka, D. H., Pérez, M. P., López, N. N., Onco, M. I., Berretta, M. F., Benintende, G. B., 2014. PCR-based prediction of type I $\beta$-exotoxin production in Bacillus thuringiensis strains. J. Invertebr. Pathol. 122, 28-31. https://doi.org/10.1016/j.jip.2014.08.001.

Schnepf, E., Crickmore, N. V., Van Rie, J., Lereclus, D., Baum, J., Feitelson, J., Dean, D. H., 1998. Bacillus thuringiensis and its pesticidal crystal proteins. Microbiol. Mol. Biol. Rev. 62 (3), 775-806.

Sharanabasappa, K. C. M., Asokan, R., Mahadeva, S. H. M., Maruthi, M. S., Pavithra, H. B., Hegde, K., Goergen, G., 2018. First report of the fall armyworm, Spodoptera frugiperda (J E Smith) (Lepidoptera: Noctuidae), an alien invasive pest on maize in India. Pest Manage. Hortic. Ecosyst. 24 (1), 23-29. Available in: https://hdl.handle. net/10568/103519 (acessed 10 April 2019).

Shuhaimi, M., Ali, A. M., Saleh, N. M., Yazid, A. M., 2001. Utilisation of enterobacterial repetitive intergenic consensus (ERIC) sequencebased PCR to fingerprint the genomes of Bifido bacterium isolates and other probiotic bacteria. Biotechnol. Lett. 23 (9), 731-736. https://doi.org/10.1023/A:1010355003674.

Silva, F. A. A., Azevedo, C. A. V., 2016. The Assistat Software Version 7.7 and its use in the analysis of experimental data. Afr. J. Agric. Res. 11 (39), 3733-3740. https://doi.org/10.5897/AJAR2016.11522.

Silva, M. D., Bueno, F. A., Stecca, S. C., Andrade, K., Neves, J. O. M. P., Oliveira, N. M. C., 2017. Biology of Spodoptera eridania and Spodoptera cosmioides (Lepidoptera: Noctuidae) on different host plants. Fla. Entomol. 100 (4), 752-760. https://doi.org/10.1653/024.100.0423.

Sousa, P. V., Vaz, A. G., Miranda, D. S., da Costa, P. V., Almeida, A. C. S., Araújo, M. S., Jesus, F. G., 2019. Control strategies for Chrysodeixis includens and Spodoptera eridania caterpillars (Lepidoptera: Noctuidae) and selection of resistant cultivars in soybean. Aust. J. Crop Sci. 13(3), 367-371. https://doi: 10.21475/ajcs.19.13.03.p1188.
Souza, L. A., Barbosa, J. C., Carvalho, J. H. S., Santos, L. S., Fraga, D. F., Busoli, A. C., 2019. Spatial distribution of Chrysodeixis includens eggs (Walker, 1858)(Lepidoptera: Noctuidae) in soybean crop. Rev. Cienc. Agric. 17 (2), 51-57. https://doi.org/10.28998/rca.v17i2.7124.

Specht, A., Paula-Moraes, S. V., Sosa-Gómez, D. R., 2015. Host plants of Chrysodeixis includens (Walker) (Lepidoptera, Noctuidae, Plusiinae). Rev. Bras. Entomol. 59 (4), 343-345. https://doi.org/10.1016/j. rbe.2015.09.002.

Valicente, F. H., Barreto, M. R., 2003. Bacillus thuringiensis survey in Brazil: geographical distribution and insecticidal activity against Spodoptera frugiperda (JE Smith) (Lepidoptera: Noctuidae). Neotrop. Entomol. 32 (4), 639-644. https://doi.org/10.1590/S1519566X2003000400014.

Valicente, F. H., Lana, U. D. P., 2008. Molecular characterization of the Bacillus thuringiensis (Berliner) strains 344 and 1644, efficient against fall armyworm Spodoptera frugiperda (JE Smith). Rev. Bras. Milho Sorgo 7 (3), 195-209. https://doi.org/10.18512/1980-6477/ rbms.v7n03p\%25p.

Valicente, F. H., Mourão, A. H., 2008. Use of by-products rich in carbon and nitrogen as a nutrient source to produce Bacillus thuringiensis (Berliner)-based biopesticide. Neotrop. Entomol. 37 (6), 702-708. https://doi.org/10.1590/S1519- 566X2008000600012.

Valicente, F. H., Picoli, E. A., Vasconcelos, M. J. V., Carneiro, N. P., Carneiro, A. A., Guimarães, C. T., Lana, U. G., 2010. Molecular characterization and distribution of Bacillus thuringiensis cry1 genes from Brazilian strains effective against the fall armyworm, Spodoptera frugiperda. Biol. Control 53 (3), 360-366. https://doi. org/10.1016/j.biocontrol.2010.02.003.

Van Frankenhuyzen, K., 2009. Insecticidal activity of Bacillus thuringiensis crystal proteins. J. Invertebr. Pathol. 101 (1), 1-16. https://doi. org/10.1016/j.jip.2009.02.009.

Wang, Z., Fang, L., Zhou, Z., Pacheco, S., Gómez, I., Song, F., Soberón, M., Zhang, J., Bravo, A., 2018. Specific binding between Bacillus thuringiensis Cry9Aa and Vip3Aa toxins synergizes their toxicity against Asiatic rice borer (Chilo suppressalis). J. Biol. Chem. 293 (29), 11447-11458. https://doi.org/10.1074/jbc.RA118.003490.

World Health Organization - WHO, 1999. Bacillus thuringiensis: environmental Health Criteria, WHO, Geneva, pp. 217. 